\title{
The effects of business environment and supply chain governance on business strategies and company performance
}

\author{
Bahtiar Arif $^{\mathrm{a}^{*}}$, Ernie Tisnawati Sule ${ }^{\mathrm{a}}$, Aldrin Herwany ${ }^{\mathrm{a}}$ and Erie Febrian ${ }^{\mathrm{a}}$
}

${ }^{a}$ Padjadjaran University, Bandung, Indonesia

\begin{tabular}{|c|c|}
\hline A B S T RA C T & \\
\hline $\begin{array}{l}\text { Article history: } \\
\text { Received July } 18,2021 \\
\text { Received in revised format } \\
\text { September } 24,2021 \\
\text { Accepted October } 262021 \\
\text { Available online } \\
\text { October } 272021 \\
\text { Keywords: } \\
\text { Business Environment } \\
\text { Supply Chain Governance } \\
\text { Business Strategy } \\
\text { Business Performance }\end{array}$ & $\begin{array}{l}\text { This study aims to examine the effects of the business environment and supply chain governance } \\
\text { on business strategies and their impact on the performance of state-owned enterprises in Indonesia. } \\
\text { Using Partial Least Square (PLS) and quantitative research, this study took state companies } \\
\text { management and commissioners as the respondents. The study concludes that the business } \\
\text { environment has a positive and significant effect on business strategy, and supply chain } \\
\text { governance has a positive and significant effect on business strategy. Moreover, the results show } \\
\text { that the business environment influences corporate performance, and supply chain governance has } \\
\text { an effect on corporate performance. Business strategy influences corporate performance, and } \\
\text { business strategy can mediate the influence of the business environment on corporate performance. } \\
\text { Lastly, business strategy can mediate the influence of supply chain governance on corporate } \\
\text { performance. The results theoretically confirm the supply chain governance in business practice } \\
\text { and practically encouraged the company management to develop risk-management and effective } \\
\text { internal controls to create competitive business climate and more agile supply chain management. }\end{array}$ \\
\hline
\end{tabular}

(C) 2022 Growing Science Ltd. All rights reserved.

\section{Introduction}

As they have important roles in many countries, the performance of state-owned enterprises (SOEs) has been paid attention, especially its contribution to the national economy. Their profitability and other financial performance indicators have been challenged. Studies on business performance of SOEs have been conducted (Shawtari et al., 2017; Yu \& Lee, 2016; Wang et al., 2016; Subramanian, 2015; Hu \& Leung, 2012). Heo (2018) by quoting World Bank study in 2014 shows that SOEs played significantly to the national economy of developed and developing countries. They contributed $20 \%$ of global/international investments and created a 5\% workforce. They also took more than 10\% of World big companies. However, SOEs have also faced challenges such as their financial performance, services, debt due date, budget constraint, less-competitive climate, inefficiency, and other unsatisfied performance results relative to those of private companies in their same industries (Riswanto, 2021). This hinders fiscal burden and risks for a state. State-owned enterprises (SOEs) in Indonesia have grown as state investment increased. Based on Central Government Consolidated Financial Statements of the Republic of Indonesia for the year 2011 to 2019 , growth of the state investments on SOEs touched its peak as $47,79 \%$ in 2015. Their profits were around 5,56\% to 8,08\% of Indonesian GDP, and 30\% of 113 SOEs reported losses (BPK RI, 2020). Some studies disclose that performance of companies is influenced by company's business strategies (Kaliappen \& Hilman, 2013; Nupus \& Ichwanudin, 2021; Laukkanen et al., 2013; Vickery et al., 2003). Business strategies are coordinated actions applied by companies to achieve their competitive advantages in product markets (Hitt et al., 2015). Nonetheless, a less optimal business strategy phenomena of SOEs in Indonesia can be seen such as disharmony strategies in up and down stream as well as cross sectoral business development, competition and business overlaps in same industrial sectors, lack of business differentiating capabilities and innovation (SOE Ministry, 2020). On the other hand, a study reveals that privatized SOEs

* Corresponding author

E-mail address: bahtiararif.unpadbdg@gmail.com (B. Arif)

(C) 2022 Growing Science Ltd. All rights reserved.

doi: $10.5267 /$ j.uscm.2021.10.012 
records better performance in terms of profit and return on assets (ROA) generation than that of fully owned SOEs (Astami et al., 2010). In achieving better performance, companies need effective business strategies as they are affected by conducive business environment (Qi et al., 2011; Amoako-Gyampah, 2003; Ward et al., 1995), and good supply chain governance (Boström et al., 2015; Vurro et al., 2009; Bitran et al., 2007). Business environment is an external and internal influence to companies (Krapez et al., 2012). Ministry of SOEs in Indonesia (2020) identifies phenomena of business environment of Indonesian SOEs, such as complexity and overlaps of cross sector regulations, multi stakeholders, and less-effective decision making, difficulties to hire best talent, not output oriented and bureaucratic management, gaps in HR management among SOEs, and talent shortage for director positions. Supply chain governance consists of rules in managing relations among shareholders, management, creditors, government, employees, and other stakeholders in implementing their rights and obligations in managing company supply chains. It is a system in controlling companies (Mughal, 2019). Dual or multiple positions are common in SOEs as 397 state officials are also posted as commissioners (Ombudsman RI, 2020). This study is intended to measure influence of business environment and supply chain governance on business strategies and their impact on Company performance in Indonesia.

\section{Literature review}

Business environment relates to company ability to adapt and anticipate external and internal influence which affects company management processes (David \& David, 2015; Kruse, 2013; Wheelen et al., 2012). This can be measured through internal and external company dimensions (Struwig et al., 2019; Chadee \& Roxas, 2013; Lim et al., 2010). Supply chain governance (SCG) focuses on implementing policies and regulations by leading, controlling and guiding the supply chain for the creation of supply chain efficiency with institutional arrangements, structures and systems. Specifically, in institutional governance, SCG is to manage relations among shareholders, shareholders, management, creditors, government, employees, and other stakeholders (Kataike et al., 2019; Sadma, 2021). One of supply chain governance goals is to have protection, equal treatment, and added values for all stakeholders to create greater efficiency (Haat et al., 2008; OECD, 2004; FCGI, 2001). Institutional supply chain governance can be measured through dimensions such as commitment in implementing it, roles of shareholders, board of directors, board of commissioners, information disclosures and transparency, and internal controls (Kataike et al., 2019; Gakpo et al., 2021; Oruke et al., 2020; Zuchruf et al., 2019). Business strategy is commitment and integrated and coordinated actions applied by companies in achieving competitive advantages by utilizing their core competencies in markets (Pearce \& Robinson, 2015; Hubbard \& Beamish, 2011). This business strategy can be measured by dimensions such as cost leadership strategy, differentiation strategy (Lopez-Cabarcos et al., 2015; Chang \& Chuang, 2011). Company performance is achievement of company activities in certain periods with such measures (David \& David, 2015; Hubbard \& Beamish, 2011). This performance can be measured by financial and non-financial dimensions (Manes-Rossi et al., 2020; Coletta \& Lima, 2020; Muin et al., 2020; Pham \& Nguyen, 2019; Khongmalai \& Distanont, 2017). Based on the descriptions, the following hypotheses were proposed:

$\mathbf{H}_{1}:$ There is a significant effect of business environment on business strategy.
$\mathbf{H}_{2}$ : Supply chain governance has a significant effect on business strategy.
$\mathbf{H}_{3}$ : There is a significant effect of business environment on company performance.
$\mathbf{H}_{4}$ : Supply chain governance has a significant effect on company performance.
$\mathbf{H}_{5}:$ There is a significant effect of business strategy on company performance.
$\mathbf{H}_{6}:$ Business strategy mediates the relationship between business environment on company performance.
$\mathbf{H}_{7}$ : Business strategy mediates the relationship between supply chain governance on company performance.

\section{Research method}

This study uses quantitative research with the explanatory survey method. In this method, hypotheses are tested by a relevant statistical analysis technique. The explanatory survey method is applied to find cause-effect relationships and test influence of independent variables on dependent variables (Sekaran \& Bougie, 2016). The sample is all SOEs, which are 113 companies in Indonesia. Samples are taken by using simple random sampling. This study collected questionnaires from company directors and commissioners. The study data are collected from questionnaires using Likert Scale 1-5 with such grades, which are $1=$ strongly disagree to $5=$ strongly agree. Data are analysed by the descriptive analysis of respondent characteristics and the Partial Least Square (PLS) analysis. The descriptive analyses of respondent characteristics are conducted by applying SmartPLS $3^{\text {rd }}$ version (Indriyanto \& Supomo, 2002).

\section{Results}

To test the validity and reliability, the outer model involves tests of discriminant validity, and composite reliability. Table 1 reveals that all indicators have loading factor values $>0.7$ and all constructs have AVE $>0.5$. Therefore, convergent validity is accepted as required. Second, the discriminant validity is tested by the square root of AVE, the Fornell-Larcker Criterion (Garson, 2016). As AVE square root values of all latent variables are higher than those of all correlations with other variables. Furthermore, the composite reliability test by Cronbach's alpha results shows that all constructs meet criteria of composite 
reliability. Table 1 discloses the Cronbach's alpha of $0.991>0.7$ and composite reliability of $0.991>0.7$. All measures confirm that the model is valid and reliable.

Table 1

Discriminant Validity and Cronbach's alpha

\begin{tabular}{llllll}
\hline Variable & SCG & PERF & BE & BS & Cronbach's alpha \\
\hline SCG & 0.901 & & & 0.990 \\
PERF & 0.834 & 0.923 & 0.898 & 0.991 \\
BE & 0.795 & 0.871 & 0.697 & 0.986 \\
BS & 0.670 & 0.832 & 0.936 & 0.984
\end{tabular}

Valid: $\sqrt{\mathrm{AVE}}>\mathrm{r} ; \sqrt{\mathrm{AVE}}$ PERF $=0,923 ; \sqrt{\mathrm{AVE}} \mathrm{SCG}>0,901 ; \sqrt{\mathrm{AVE}} \mathrm{BE}=0,898 ; \sqrt{\mathrm{AVE}} \mathrm{BS}=0,936$

To examine Goodness of Fit, this study uses the R Square, Q Square, and Standardized Root Mean Square Residual (SRMR) values to assess the goodness of fit. Chin (1998) argues that the R square value of 0.67 shows a strong model; 0.33 moderate, and 0.19 weak. Q square value is categorized by small, moderate, and big. Q square value is 0.02 , it is small, Q square is 0.15 medium, Q square is 0.35 , big. SRMR explains good fit, with perfect fit model if $\mathrm{SRMR}<0.08$; fit model for SRMR between $0.08-0.10$. and not fit model, for SRMR $>0.10$. Table 2 reveals the goodness of fit of this research supported by strong and moderate endogen variables (R Square) big Q Square and fit (SRMR $0.08-0.10$ ).

Table 2

Goodness of Fit

\begin{tabular}{|c|c|c|c|}
\hline \multirow{2}{*}{ Endogen Variable } & \multicolumn{3}{|c|}{ Goodness of Fit Model Parameter } \\
\hline & $\bar{R}$ Square & Q Square & SRMR \\
\hline$\overline{\text { KIN }}$ & 0.882 & 0.743 & 0.045 \\
\hline SB & 0.522 & 0.451 & \\
\hline
\end{tabular}

R-Square: 0.67 strong; 0.33 moderate; 0.19 weak. Q-square: 0.02 small; 0.15 medium; 0.35 big. SRMR: $<0.10$ fit

Moreover, adjusted R-Square shows the determination coefficient which describes contributions of all exogen and endogen variables. Table 2 reveals that the adjusted R-Square of the performance is 0.878 . This means that $87,8 \%$ the Company performance is affected by business environment, supply chain governance, and business strategy, and the rest $12,8 \%$ the Company performance is influenced by other variables. Furthermore, the business environment and supply chain governance contribute $51.1 \%$ to the business strategy, and the rest of $48.9 \%$ affected by other variables as represented by the value of the adjusted R-square.

Table 3

Direct Effect

\begin{tabular}{|c|c|c|c|c|}
\hline \multicolumn{2}{|l|}{ Path } & \multirow{2}{*}{$\begin{array}{l}\text { Path Coefficient } \\
0.266\end{array}$} & \multirow{2}{*}{$\begin{array}{l}\text { T statistics (|O/STDEV } \mid) \\
3.624\end{array}$} & \multirow{2}{*}{$\begin{array}{l}\text { p-values } \\
0.000\end{array}$} \\
\hline - & SCG $\rightarrow$ PERF & & & \\
\hline$\bullet$ & $\mathrm{SCG} \rightarrow \mathrm{BS}$ & 0.317 & 2.808 & 0.005 \\
\hline$\bullet$ & BE $\rightarrow$ PERF & 0.397 & 4.898 & 0.000 \\
\hline • & $\mathbf{B E} \rightarrow \mathbf{B S}$ & 0.445 & 3.494 & 0.001 \\
\hline$\bullet$ & BS $\rightarrow$ PERF & 0.377 & 4,873 & 0.000 \\
\hline
\end{tabular}

As to examine the direct effects, Table 3 shows direct effect and significance test results. The analysis with path found the influence of business environment on business performance (BE $\rightarrow$ PERF, p-value is 0.000 with T-stat. $=4.898$ and positive path coefficient of 0.397 . Because the results showed the value is acceptable by using the criteria of $p$-value $<0.05$, T-stat. $>1.96$, and positive path coefficient, so that business environment has positive influence and significance on the business performance. Thus, the first hypothesis was accepted. Path analysis also showed the influence of supply chain governance on business performance (SCG $\rightarrow$ PERF), p-value is 0.000 . with T-stat. $=3.624$, and positive path coefficient $(0.266)$. The path analysis results confirmed that the value is acceptable by using the criteria of p-value $<0.05, \mathrm{~T}$-stat. $>1.96$, and positive path coefficient. Thus, the second hypothesis stating that supply chain governance has positive influence and significance on the business performance was accepted. Regarding the influence of the business environment on business strategy (BE $\rightarrow$ $\mathrm{BS})$, the results showed that $\mathrm{p}$-value is $0.001(<0.05)$ with $\mathrm{T}$-stat. $=3.494(>1.96)$, and a positive path coefficient of 0.445 . This confirms that the business environment has a positive influence and significance on the business strategy. Thus, the third hypothesis was accepted. Moreover, path analysis showed the influence of supply chain governance on business strategy $(\mathrm{SCG} \rightarrow \mathrm{BS})$, p-value is 0.005 with T-stat. $=2.808$, path coefficient is 0.317 . Compared with the acceptance limit by using the criteria of $p$-value $<0.05$, t-stat. $>1.96$, and positive path coefficient, the results confirmed that supply chain governance has positive influence and significance on business strategy. Therefore, the fourth hypothesis was accepted. Lastly, the path results showed the influence of business strategy on company performance (BS $\rightarrow$ PERF), indicated by $p$-value is 0.000 
$(<0.05)$ with T-stat. of $4.873(>1.96)$, and path coefficient $(+) 0.377$. Thus, the fifth hypothesis stating that business strategy has positive influence and significance on the business performance was accepted.

Table 4

Indirect Effect

\begin{tabular}{cccc}
\hline Indirect Path & Indirect Path Coefficient & T-statistics & $p$-values \\
\hline $\mathrm{BE} \rightarrow \mathrm{BE} \rightarrow$ PERF & 0.168 & 2.638 & 0.009 \\
$\mathrm{SCG} \rightarrow \mathrm{BS} \rightarrow$ PERF & 0.119 & 2.250 & 0.025 \\
\hline
\end{tabular}

Significance level 5\%; significant path coefficient if $\mathrm{p}$-value $<0.05$ and $\mathrm{T}$ statistics $>1.96$

Furthermore, to examine the indirect effect, in this study, the business strategy is the intervening variable, which mediates influence of business environment and supply chain governance on the company performance. To test the contribution of this business strategy in mediating those variables, indirect influence is tested by specific indirect effect PLS analysis. Table 4 reveals that the indirect effect $\mathrm{p}$-value business environment and supply chain governance on the company performance through business strategy. First on the path of business environment indirect effect to the company performance through the business strategy, the test results in p-value is $0.009<0.05$ and t-stat. is $2.638>1.96$. This concludes that business strategy is significant in mediating indirect influence of the business environment on the company performance. Thus, the seventh hypothesis highlighting the mediating effect of business strategy on business environment and the performance is accepted. Second, on the indirect effect of supply chain governance on the Company performance through the business strategy, pvalue is $0.025<0.05$ with $\mathrm{t}$-stat. of $2.250>1.96$. This means that the business strategy significantly mediates indirect supply chain governance on the performance. Thus, the seventh hypothesis highlighting the mediating effect of business strategy on supply chain governance and the performance is accepted.

\section{Table 5}

Hypothesis Test Results

\begin{tabular}{|c|c|c|c|}
\hline No & Hhypotheses & Results & Conclusions \\
\hline 1 & $\begin{array}{l}\text { Business environment has a significant effect on business } \\
\text { strategy }\end{array}$ & $\begin{array}{l}\text { Path coefficient }=0.445 ; \text { t-stat. }=3.494 ; \mathrm{p}- \\
\text { value }=0.001\end{array}$ & Accepted \\
\hline 2 & $\begin{array}{l}\text { Supply chain governance has a significant effect on business } \\
\text { strategy }\end{array}$ & $\begin{array}{l}\text { Path coefficient }=0.317 ; \text { t-stat. }=2.808 ; \mathrm{p}- \\
\text { value }=0.005\end{array}$ & Accepted \\
\hline 3 & $\begin{array}{l}\text { Business strategy has a significant effect on company } \\
\text { performance }\end{array}$ & $\begin{array}{l}\text { Path coefficient }=0.397 ; \text { t-stat. }=4.898 ; \mathrm{p}- \\
\text { value }=0.000\end{array}$ & Accepted \\
\hline 4 & $\begin{array}{l}\text { Supply chain governance has a significant effect on } \\
\text { company performance }\end{array}$ & $\begin{array}{l}\text { Path coefficient }=0.266, \mathrm{t} \text {-stat. }=3.624 ; \mathrm{p}- \\
\text { value }=0.000\end{array}$ & Accepted \\
\hline 5 & $\begin{array}{l}\text { Business strategy has a significant effect on company } \\
\text { performance }\end{array}$ & $\begin{array}{l}\text { Path coefficient }=0.377, \text { t-stat. }=4.873 ; \mathrm{p}- \\
\text { value }=0.000\end{array}$ & Accepted \\
\hline 6 & $\begin{array}{l}\text { Business strategy mediates the relationship of business } \\
\text { environment on company performance }\end{array}$ & $\begin{array}{l}\text { Path coefficient }=0.168, \text { t-stat. }=2.638 ; \mathrm{p}- \\
\text { value }=0.009\end{array}$ & Accepted \\
\hline 7 & $\begin{array}{l}\text { Business strategy mediates the relationship of supply chain } \\
\text { governance on company performance }\end{array}$ & $\begin{array}{l}\text { Path coefficient }=0.119 ; \text { t-stat. }=2.250 ; \mathrm{p}- \\
\text { value }=0.025\end{array}$ & Accepted \\
\hline
\end{tabular}

Significance Level 5\%; hypothesis is accepted if p-value $<0.05$; $t$-stat. $>1.96$ (two tail test)

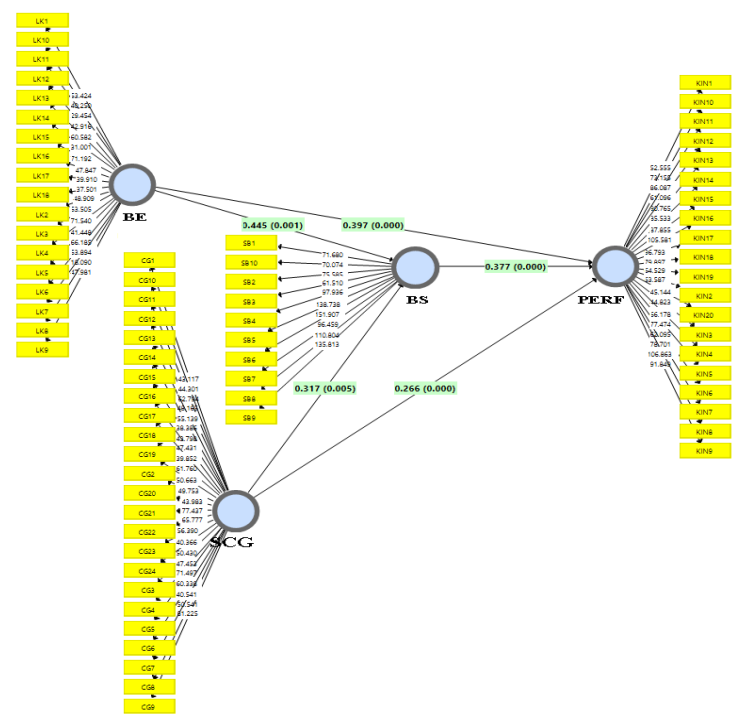

Fig. 1. Estimated Result of PLS Model - Bootstrapping 


\section{Conclusion}

The study concludes that the business environment has a positive and significant effect on business strategy, and supply chain governance has a positive and significant effect on business strategy. Moreover, the results showed that the business environment influences corporate performance, and supply chain governance influences corporate performance. Business strategy influences corporate performance, and business strategy can mediate the influence of the business environment on corporate performance. Lastly, business strategy can mediate the influence of supply chain governance on corporate performance. Statistically, the the results showed that the path coefficient measuring influence of business environment on performance is 0.397 , and that of supply chain governance on performance is 0.266 ; and that of business strategy on performance is 0.377 . This means that the most influenced variables on the company performance are business environment and business strategy, besides supply chain governance. Furthermore, business environment affects strongly relative to supply chain governance on business strategy as path coefficient of business environment on business strategy is greater (0.445) that of supply chain governance on business strategy (0.317). This study suggests company management and governments to improve performance of SOEs. First, regarding the business environment, the company should have qualified human resources who meet competence standards, a consistent reward and punishment system, commitment, and quick response to latest technologies. In the supply chain governance, company management should develop risk-management and effective internal controls to create more agile supply chain management. In terms of the business strategy, quick response of emerging market changes, new product development, new brand development, and cost efficiency of production must be considered as the business strategy. Regarding company performance, the management needs to estimate, do best, monitor periodically on sales growth, net profit, return on equity (ROE), return on asset (ROA), and return on investment (ROI). As one of the specific items in supply chain governance, particularly for state companies, government and regulators are advised to restructure the organizations to make the companies more agile in doing their businesses, to measure burden and costs of the companies in conducting public service obligations required by the government. For future research, it is hoped that next research examines different models of research which can be developed by considering other independent and intervening variables which may affect company performance. Some variables such as company capabilities and transformational leadership can be considered to have influence on the business strategy and performance.

\section{References}

Amoako-Gyampah, K. (2003). The relationships among selected business environment factors and manufacturing strategy: insights from an emerging economy. Omega, 31(4), 287-301.

Astami, E. W., Tower, G., Rusmin, R., \& Neilson, J. (2010). The effect of privatisation on performance of state-owned-enterprises in Indonesia. Asian Review of Accounting, 18(1), 5-19.

Bitran, G. R., Gurumurthi, S., \& Sam, S. L. (2007). The need for third-party coordination in supply chain governance. MIT Sloan Management Review, 48(3), 30.

Boström, M., Jönsson, A. M., Lockie, S., Mol, A. P., \& Oosterveer, P. (2015). Sustainable and responsible supply chain governance: challenges and opportunities. Journal of Cleaner Production, 107, 1-7.

Chadee, D.\& Roxas, B. (2013). Institutional environment, innovation capacity and firm performance in Russia. Critical perspectives on international business, 9(1/2), 19-39.

Chang, T.C., \& Chuang, S.H. (2011). Performance implications of knowledge management processes: Examining the roles of infrastructure capability and business strategy. Expert Systems with Applications, 38, 6170-6178.

Chin, W. W. (1998). The partial least squares approach to structural equation modeling. In G. A. Marcoulides (Ed.). Modern Methods for Business Research (pp. 295-358). Mahwah: Erlbaum.

Coletta, C., \& Lima, R.A.S. (2020). Board of directors, performance and firm value in Brazilian listed state-owned enterprises. Brazilian Review of Finance, Rio de Janeiro, 18(2), 2020),1-28.

David, F.R., \& David, F.R. (2015), Strategic Management, Concepts \& Cases, $5^{\text {th }}$ Ed. Pearson Education Limited. England.

Dolci, P. C., Maçada, A. C. G., \& Paiva, E. L. (2017). Models for understanding the influence of supply chain governance on supply chain performance. Supply Chain Management: An International Journal, 22(5), 424-441

Forum for Corporate Governance in Indonesia: FCGI. (2001). Corporate Governance. Jakarta.

Gakpo, M.D., Ashigbey, Y.K.K., \& Kwakye, M. (2021). Corporate governance and performance of state-owned enterprises in Ghana. International Academic Journal of Economics and Finance, 3(6), 333-344.

Garson, G. D. (2016). Partial least square: Regression and structural equation models. Asheboro: Statistical Associates Publishing.

Haat, M.H.C., Rahman, R.A., \& Mahenthiran, S. (2008). Corporate governance, transparency and performance of Malaysian companies. Managerial Auditing Journal, 23(8), 744-778.

Heo, K., (2018). Effects of Corporate Governance on the Performance of State-Owned Enterprises. World Bank Policy Research Working Paper No. 8555.

Hitt, M.A., Ireland, R.D., Hoskisson, R.E. (2015). Strategic Management: Competitiveness \& Globalization: Concepts and Cases, $11^{\text {th }}$ Ed. Stamford. Cengage Learning.

Hu, F., \& Leung, S.C.M. (2012). Top management turnover, firm performance and government control: Evidence from China's listed stateowned enterprises. The International Journal of Accounting, 47(2), 235-262.

Hubbard, G., \& Beamish, P. (2011). Strategic Management - Thinking, Analysis, Action, $4^{\text {th }}$ Ed. Pearson Australia.

Indriyanto, N., \& Supomo, B. (2002). Business Research Methodology. Penerbit BFEE UGM.

Kaliappen, N., \& Hilman, H. (2013). Enhancing Organizational Performance Through Strategic Alignment of Cost Leadership Strategy and Competitor Orientation. Middle-East Journal of cientific Research 18(10), 1411-1416, 2013.

Kataike, J., Molnar, A., De Steur, H., \& Gellynck, X. (2019). Examining the relationship between chain governance structures and chain performance: an empirical evidence of the dairy sector. British Food Journal, 121(8), 1850-1870. 
Khongmalai, O., \& Distanont, A. (2017). Corporate governance model in Thai state-owned enterprises: structural equation modelling approach. Corporate Governance: The International Journal of Business in Society, 17(4), 613-628.

Krapez, J., Groznik, A., \& Skerlavaj, M. (2012). Contextual Variables of Open Innovation Paradigm in the Business Environment of Slovenian Companies. Economic and Business Review for Central and South - Eastern Europe 14(1), 17-38.

Kruse, C., (2013). An Analysis of the External Environmental and Internal Organizational Factors Associated with Adoption of the Electronic Health Record. Dissertation, Virginia Commonwealth University VCU Scholars Compass.

Laukkanen, T., Nagy, G., Hirvonen, S., Reijonen, H., \& Pasanen, M. (2013). The effect of strategic orientations on business performance in SMEs: A multigroup analysis comparing Hungary and Finland. International Marketing Review, 30(6), 510-535.

Lim, D. S., Morse, E. A., Mitchell, R. K., \& Seawright, K. K. (2010). Institutional environment and entrepreneurial cognitions: A comparative business systems perspective. Entrepreneurship theory and Practice, 34(3), 491-516.

Lopez-Cabarcos, M. A., Gottling-Oliveira-Monteiro, S., \& Vazquez-Rodriguez, P. (2015). Organizational Capabilities and Profitability: The Mediating Role of Business Strategy. SAGE Open October - December 2015: 1-13.

Manes-Rossi, F., Nicolo, G., Tudor, A.T., \& Zanellato, G. (2020). Drivers of integrated reporting by state-owned enterprises in Europe: a longitudinal analysis. Meditari Accountancy Research.

Mughal, M. (2019). Impact of green supply chain management practices on performance of manufacturing companies in Jordan: A moderating role of supply chain traceability. Arthatama, 3(2), 67-82.

Muin, M.F., Jumadi, \& Wardini, A.K. (2020). Study of State-Owned Enterprises (SOEs) Profitability in Indonesia 2012-2016 Period. Sriwijaya International Journal of Dynamic Economics and Business, 4(1), 2020, 57-72.

Nupus, H., \& Ichwanudin, W. (2021). Business Network Accessibility, Customer Relationship Management and Value Co-creation on Family Business Performance. Research Horizon, 1(4), 126-135.

Ombudsman of the Republic of Indonesia: Ombudsman RI. (2020). 397 SOE's Commissioners Indicated for Multiple Positions in 2019. Retrieved from https:/ombudsman.go.id/news/r/ombudsman-ri-397-komisaris-bumn-terindikasi-rangkap-jabatan-pada-2019

Organization for Economic Cooperation and Development: OECD. (2004). Principles of Corporate Governance. The OECD Paris.

Oruke, M., Iraya, C., Odhiambo, L. O., \& Omoro, N. O. (2020). Corporate Governance and Modified Audit Opinion: Evidence from State Owned Enterprises in Kenya. Journal of Accounting, Finance and Auditing Studies, 6(4), 96-110.

Pearce, J.A., \& Robinson, R.B. (2015). Strategic Management: Planning for Domestic \& Global Competition, International Ed. New York. McGraw Hill.

Pham, D. C., \& Nguyen, T. X. H. (2019). The influence of privatization on financial performance of Vietnamese privatized state-owned enterprises. Investment Management \& Financial Innovations, 16(3), 341.

Qi, Y., Zhao, X., \& Sheu, C. (2011). The impact of competitive strategy and supply chain strategy on business performance: the role of environmental uncertainty. Decision Sciences, 42(2), 371-389.

Quyen, T. (2020). The Relationship between Green Procurement Practices and Organizational Performance in the Manufacturing Industry of Vietnam. Arthatama, 4(1), 1-16.

Riswanto, A. (2021). Competitive Intensity, Innovation Capability and Dynamic Marketing Capabilities. Research Horizon, 1(1), 7-15.

Sadma, O. (2021). The Role of Environmental-Based "Green Startup" in Reducing Waste Problem and its Implication to Environmental Resilience. Research Horizon, 1(3), 106-114.

Sekaran, U., \& Bougie, R. (2016). Research methods for business: A skill building approach. John Wiley \& Sons.

Shawtari, F.A., Har Sani Mohamad, M., Abdul Rashid, H.M., \& Ayedh, A.M. (2017). Board characteristics and real performance in Malaysian state-owned enterprises (SOEs). International Journal of Productivity and Performance Management, 66(8), $1064-1086$.

Struwig, F.W., Kruger, J., \& Nuwagaba, G. (2019). The influence of the business environment on the growth of informal businesses in Uganda. Southern African Journal of Entrepreneurship and Small Business Management 11 (1), a200.

Subramanian, S. (2015). Corporate Governance, Institutional Ownership and Firm Performance in Indian State-owned Enterprises. AsiaPacific Journal of Management Research and Innovation, 11(2), 117-127.

The Audit Board of the Republic of Indonesia: BPK RI. (2020). Summary of examination results, semester II 2020. Retrieved from https://www.bpk.go.id/ihps

The Ministry of State Owned Enterprises of the Republic of Indonesia. (2020). Strategic plan of the ministry of state owned enterprises of the republic of Indonesia 2020-2024. Retrieved from https://jdih.bumn.go.id/baca/PER-08/MBU/08/2020.pdf

Vickery, S.K., Jayaram, J., Droge, C. \& Calantone, R. (2003). The effects of an integrative supply chain strategy on customer service and financial performance: an analysis of direct versus indirect relationships. Journal of Operations Management 21 (2003) $523-539$.

Vurro, C., Russo, A., \& Perrini, F. (2009). Shaping sustainable value chains: Network determinants of supply chain governance models. Journal of business ethics, 90(4), 607-621.

Wang, Y., Jin, P., \& Yang, C. (2016). Relations between the professional backgrounds of independent directors in state-owned enterprises and corporate performance. International Review of Economics \& Finance, 42, 404-411.

Ward, P.T., Duray, R., Leong, G.K., \& Sum, C.C. (1995). Business environment, operations strategy, and performance: An empirical study of Singapore manufacturers. Journal of Operations Management 13 (1995) 99-115.

Wheelen, T.L., Hunger, J.D., Hoffman, A.N., Bamford, C.E. (2015). Strategic Management and Business Policy: Globalization, Innovation, and Sustainability, $14^{\text {th }}$ Ed., Global Ed. Pearson.

Yu, S., \& Lee, N. (2016). Financial Crisis, Politically Connected CEOs, and the Performance of State-Owned Enterprises: Evidence from Korea. Emerging Markets Finance and Trade, 52(9), 2087-2099.

Zuchruf, F., Suhadak, Mangesti, R.S., \& Muhammad, S. (2019). The effect of Corporate Governance, Firm size and capital structure on financial performance: a study of State-Owned Enterprises listed in the Indonesia stock Exchange during period of 2013-2016. RJOAS, 9(93), September 2019.

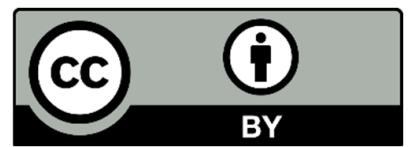

(C) 2022 by the authors; licensee Growing Science, Canada. This is an open access article distributed under the terms and conditions of the Creative Commons Attribution (CCBY) license (http://creativecommons.org/licenses/by/4.0/). 